\title{
HUBUNGAN STATUS GIZI DAN KUALITAS TIDUR DENGAN KUALITAS HIDUP PADA LANJUT USIA
}

\author{
Febriyanti Hermawan, Nurmasari Widyastuti", A Fahmy Arif Tsani, Deny Yudi Fitranti \\ Departemen Ilmu Gizi, Fakultas Kedokteran, Universitas Diponegoro \\ Jl. Prof. Sudarto SH, Tembalang, Semarang, Jawa Tengah 50275, Indonesia \\ "Penulis Penanggungjawab. E-mail: widyastutinurmasari@gmail.com
}

\begin{abstract}
Background: The number of elderly people increases every year. Increasing the quantity of the elderly must be balanced with improving the quality of life. Nutritional status and quality of sleep is a problem experienced by the elderly. This study aims to analyze the relationship between nutritional status and sleep quality with quality of life in the elderly.

Method: This study uses a cross-sectional method. This research was conducted in Kalisegoro, Gunungpati, Semarang. Based on the results of screening 254 elderly people obtained 44 subjects using the simple random sampling method. Nutritional status data is obtained through direct measurements using digital scales and knee height gauges. Data on sleep quality and quality of life were obtained through interviews using the Pittsburgh Sleep Quality Index (PSQI) and World Health Organization Quality of Life (WHOQOL-BREF) forms.

Results: There was no correlation between nutritional status and quality of life $(r=0.251 ; p=0.101)$ and there was no correlation between sleep quality and quality of life ( $r=0.027 ; p=0.862)$.

Conclusion: There is no relationship between nutritional status and sleep quality with quality of life in the elderly.
\end{abstract}

Keywords: Nutritional status; sleep quality; quality of life; elderly.

\begin{abstract}
ABSTRAK
Latar Belakang : Jumlah penduduk lanjut usia mengalami peningkatan setiap tahunnya. Peningkatan kuantitas lanjut usia harus diseimbangkan dengan peningkatan kualitas hidupnya. Status gizi dan kualitas tidur menjadi masalah yang dialami oleh lansia. Penelitian ini bertujuan untuk menganalisis hubungan status gizi dan kualitas tidur dengan kualitas hidup pada lanjut usia.

Metode : Penelitian ini menggunakan metode cross-sectional. Penelitian ini dilaksanakan di Kelurahan Kalisegoro Kecamatan Gunungpati Kota Semarang. Berdasarkan hasil skrining 254 lanjut usia didapatkan 44 subjek menggunakan metode simple random sampling. Data Status gizi didapatkan melalui pengukuran langsung menggunakan timbangan digital dan alat pengukur tinggi lutut. Data kualitas tidur dan kualitas hidup diperoleh melalui wawancara menggunakan form Pittsburgh Sleep Quality Index (PSQI) dan World Health Organization Quality of Life (WHOQOL-BREF).

Hasil : Tidak terdapat hubungan antara status gizi dengan kualitas hidup $(r=0,251 ; p=0,101)$ dan tidak terdapat hubungan antara kualitas tidur dengan kualitas hidup $(r=0,027 ; p=0,862)$.

Simpulan : Tidak terdapat hubungan antara status gizi dan kualitas tidur dengan kualitas hidup pada lanjut usia.
\end{abstract}

Kata Kunci : Status gizi; kualitas tidur; kualitas hidup; lanjut usia.

\section{PENDAHULUAN}

Salah satu tolak ukur kemajuan suatu bangsa seringkali dilihat dari harapan hidup penduduknya ${ }^{1}$. Keberhasilan pembangunan, terutama di bidang kesehatan, secara tidak langsung telah menurunkan angka kesakitan dan kematian penduduk, serta meningkatkan usia harapan hidup ${ }^{2}$. Peningkatan mutu kehidupan menimbulkan perubahan strutktur penduduk dan sekaligus menambah jumlah penduduk berusia lanjut. Lanjut usia adalah seseorang yang telah mencapai usia 60 tahun. Lanjut usia merupakan tahap lanjut dari suatu proses kehidupan yang ditandai dengan penurunan kemampuan fisik dan kognitif ${ }^{3}$.

Jumlah penduduk lanjut usia mengalami peningkatan setiap tahunnya. Pada tahun 2015, presentase penduduk lanjut usia di dunia mencapai 12,3\%, $11,6 \%$ di Asia dan 8,1\% di Indonesia. Presentase tersebut diperkirakan akan mengalami peningkatan pada tahun 2025 menjadi 14,9\% di dunia, $15 \%$ di Asia dan $11,1 \%$ di Indonesia. Presentase penduduk lanjut usia menunjukan bahwa baik secara global, Asia dan Indonesia dari tahun 2015 sudah memasuki era penduduk menua karena jumlah penduduknya yang berusia 60 tahun keatas melebihi angka $7 \%^{3}$. Di Indonesia terdapat 19 provinsi yang memiliki struktur penduduk tua. Tiga provinsi dengan presentase lanjut usia terbesar adalah DI Yogyakarta $(13,81 \%)$, Jawa Tengah $(12,59 \%)$ dan Jawa Timur $(12,25 \%)^{4}$.

Peningkatan kuantitas penduduk lanjut usia harus diimbangi dengan peningkatan kualitas 
hidupnya. Lanjut usia diharapkan memiliki kualitas hidup yang baik, bahagia dan dapat melakukan aktivitas hidup secara mandiri. World Health Organization Quality of Life (WHOQOL) mendefinisikan kualitas hidup sebagai persepsi individu terhadap kehidupannya di masyarakat dalam konteks budaya dan sistem nilai yang ada yang terkait dengan tujuan, harapan, standar, dan perhatian ${ }^{5}$. Kualitas hidup merupakan suatu konsep yang sangat luas. Kualitas hidup dipengaruhi oleh beberapa faktor yaitu kondisi fisik individu, psikologis, tingkat kemandirian, serta hubungan individu tersebut dengan lingkungan ${ }^{5}$. Kondisi fisik dan psikologis yang baik akan mendukung lanjut usia untuk dapat hidup secara mandiri dan aktif dalam lingkungan sosialnya.

Kondisi fisik yang baik akan mendukung lanjut usia memiliki gaya hidup yang baik, sehingga meningkatkan status kesehatannya. Status kesehatan lanjut usia dipengaruhi oleh status gizinya. Status gizi pada lanjut usia harus mendapatkan perhatian khusus karena dapat mempengaruhi status kesehatan, penurunan kualitas hidup dan mortalitas. Gizi kurang maupun gizi lebih pada masa dewasa akhir dapat memperburuk kondisi fungsional dan kesehatan fisik $^{6}$. Hal ini menunjukan pentingnya status gizi normal untuk meningkatkan kualitas hidup pada lanjut usia.

Selain status gizi, lanjut usia juga mengalami penurunan lainnya yaitu penurunan kualitas hidup. Semakin bertambahnya usia, maka semakin bertambah juga masalah tidur yang terjadi ${ }^{7}$. Perubahan pola tidur dapat berupa tidak bisa tidur sepanjang malam dan sering terbangun pada makam hari, sehingga lanjut usia melakukan kegiatannya pada malam hari. lanjut usia berisiko mengalami gangguan tidur yang disebabkan oleh banyak faktor seperti pensiun dan perubahan pola sosial, kematian pasangan atau teman dekat, peningkatan penggunaan obat - obatan dan penyakit yang baru saja dialami ${ }^{8}$. Kualitas tidur yang buruk dapat mengakibatkan gangguan keseimbangan fisiologi dan psikologi seperti penurunan aktivitas sehari - hari, rasa capai dan lemah, daya tubuh menurun, depresi, cemas dan sulit untuk bekonsentrasi. Hal ini dapat menyebabkan kualitas hidup pada lanjut usia menurun.

Berdasarkan uraian di atas, kualitas hidup pada lanjut usia dipengaruhi oleh status gizi dan kualitas tidur. Studi yang mempelajari tentang kualitas hidup pada lanjut usia yang dikaitkan dengan status gizi dan kualitas hidup masih terbatas. Hal ini perlu menjadi perhatian karena peningkatan kualitas hidup dapat meningkatkan status kesehatan yang baik, mengurangi ketergantungan lanjut usia pada penduduk usia produktif dan penurunan angka mortalitas dan morbilitas?.

\section{METODE}

Pengambilan data dilakukan di Kelurahan Kalisegoro, Kecamatan Gunungpati, Kota Semarang pada bulan Mei 2019. Penelitian yang dilakukan merupakan penelitian dalam bidang ilmu gizi masyarakat yang sudah disertai Ethical Clearance dengan nomor 126/EC/KEPK/FK-UNDIP/V/2019. Penelitian ini merupakan penelitian observasional dengan pendekatan cross-sectional. Populasi target dalam penelitian ini adalah semua lanjut usia yang berusia 60 - 74 tahun di Kecamatan Gunungpati, Kota Semarang. Populasi terjangkau pada penelitian ini adalah lanjut usia yang berusia $60-74$ tahun di Kelurahan Kalisegoro, Kecamatan Gunungpati, Kota Semarang. Besar sampel dihitung dengan menggunakan rumus perhitungan sampel dan didapatkan sampel sebesar 44 orang. Pengambilan sampel dilakukan dengan cara simple random sampling yang memenuhi kriteria inklusi.

Kriteria inklusi subjek adalah pria dan wanita lanjut usia yang bersedia menjadi sampel penelitian dengan mengisi informed consent, berusia 60 sampai 74 tahun, dapat beraktivitas secara mandiri, dan mampu berkomunikasi dengan baik. Sedangkan kriteria eksklusi adalah pria dan wanita lanjut usia berusia $60-74$ tahun yang menderita penyakit berat sehingga harus berbaring di tempat tidur.

Variabel bebas (independen) dalam penelitian ini adalah status gizi dan kualitas tidur, variabel terikat (dependen) adalah kualitas hidup, sedangkan variabel perancu adalah status ekonomi sosial, aktivitas fisik dan kondisi psikologis. Data yang dikumpulkan antara lain identitas sampel, berat badan (BB), tinggi lutut, tinggi badan (TB), IMT, data kualitas hidup, data kualitas tidur, data tingkat stress, dan data aktivtas fisik.

Data identitas subjek diperoleh melalui wawancara. Penimbangan berat badan menggunakan timbangan injak digital dengan ketelitian $0,1 \mathrm{~kg}$. Pengukuran tinggi lutut menggunakan alat pengukur tinggi lutut (knee height caliper) dengan ketelitian 0,1 $\mathrm{cm}$. Data tinggi lutut dikonversi menjadi data tinggi badan menggunakan persamaan konversi tinggi lutut menjadi tinggi badan menurut Kemenkes yaitu TB Laki-laki $=56,543+2,102 \mathrm{TL}$ dan TB perempuan $=$ $62,682+1,889$ TL. Data BB dan TB digunakan untuk menentukan status gizi berdasarkan IMT. Data kualitas hidup diukur dengan menggunakan WHOQOL-BREF (World Health Organization Quality of Life). Data kualitas tidur diukur menggunakan PSQI (Pitssburgh Sleep Quality Index). Data tingkat stress diukur menggunakan DASS 42 (Depression Anxiety Stress Scale 42) dan data aktivitas fisik diukur menggunakan IPAQ (International Physical Activity Questionnaire). 
Tahap pertama dalam penelitian ini adalah skrinning subyek. Data umur lanjut usia didapatkan dari data lanjut usia yang dimiliki oleh Kelurahan Kalisegoro. Data lanjut usia yang berusia 60 sampai 74 tahun dipilih dengan cara simple random samping. Lanjut usia yang setuju menjadi subjek dibantu mengisi informed concent oleh enumerator yang sudah terlatih. Kemudian subjek ditimbang berat badan dan diukur tinggi lututnya. Berikutnya wawancara identitas subjek dan pengukuran kualitas hidup menggunakan WHOQOL-BREF (World Health Organization Quality of Life) dengan standar baku 0-50 untuk kualitas hidup buruk dan 50-100 untuk kualitas hidup baik, kualitas tidur menggunakan PSQI (Pitssburgh Sleep Quality Index) dengan standar baku 0-5 untuk kualitas tidur baik dan lebih dari 5 untuk kualitas tidur buruk, tingkat stress menggunakan DASS 42 (Depression Anxiety Stress Scale 42) dengan standar baku 0-14 untuk tingkat stress normal, 15-25 untuk tingkat stress sedang dan lebih dari 26 untuk tingkat stress berat dan aktivitas fisik menggunakan IPAQ (International Physical Activity Questionnaire) dengan standar baku rendah untuk tidak ada kegiatan yang memenuhi kategori dua atau tiga, sedang untuk total aktivitas fisik minimal 600 MET-menit/minggu dan tinggi untuk skor total aktivitas fisik minimal 1500 MET-menit/minggu selama tiga hari atau $3000 \mathrm{MET}$-menit/minggu.

Analisis data menggunakan software SPSS version 23. Analisis univariat digunakan untuk mendeskripsikan karateristik sampel. Data diuji normalitasnya menggunakan shapiro-wilk $(\mathrm{n}<50)$ dengan nilai kemaknaan $\mathrm{p}>0,05$. Analisis bivariat digunakan untuk mengetahui hubungan masingmasing variabel bebas dengan variabel terikat menggunakan uji korelasi Rank Spearman karena data berdistribusi tidak normal.

\section{HASIL \\ Karakteristik Subjek Penelitian}

Penelitian mengenai hubungan antara status gizi dan kualitas tidur dengan kualitas hidup yang dilaksanakan pada bulan Mei 2019 di Kelurahan Kalisegoro, Kecamatan Gunungpati, Kota Semarang. Didapatkan hasil sebagai berikut :

Tabel 1. Karateristik Subjek Penelitian

\begin{tabular}{|c|c|c|c|}
\hline Variabel $(n=44)$ & Kualitas Hidup Baik & Kualitas Hidup Buruk & n (\%) \\
\hline Usia (tahun) & & & 65,09 \\
\hline \multicolumn{4}{|l|}{ Jenis kelamin $(\mathrm{n}, \%)$} \\
\hline Perempuan & $15(75 \%)$ & $5(25 \%)$ & $20(45,5 \%)$ \\
\hline Laki - laki & $16(67 \%)$ & $8(33 \%)$ & $24(54,5 \%)$ \\
\hline \multicolumn{4}{|l|}{ Status pernikahan $(\mathrm{n}, \%)$} \\
\hline Berpasangan & $25(71,4 \%)$ & $10(28,5 \%)$ & $35(79,5 \%)$ \\
\hline Tidak Berpasangan & $6(67 \%)$ & $3(33 \%)$ & $9(20,5 \%)$ \\
\hline \multicolumn{4}{|l|}{ Tinggal dengan $(\mathrm{n}, \%)$} \\
\hline Anak & $6(85,7 \%)$ & $1(14,2 \%)$ & $7(15,9 \%)$ \\
\hline Pasangan & $22(67 \%)$ & $11(33 \%)$ & $33(75 \%)$ \\
\hline Sendiri & $2(50 \%)$ & $2(50 \%)$ & $4(9,1 \%)$ \\
\hline \multicolumn{4}{|l|}{ Pendidikan akhir (n,\%) } \\
\hline $\mathrm{SD}$ & $28(68,2 \%)$ & $13(31,8 \%)$ & $41(93,2 \%)$ \\
\hline SMP & $1(100 \%)$ & - & $1(2,3 \%)$ \\
\hline SMA & $2(100 \%)$ & - & $2(4,5 \%)$ \\
\hline \multicolumn{4}{|l|}{ Pekerjaan $(\mathrm{n}, \%)$} \\
\hline Bekerja & $17(63 \%)$ & $10(37 \%)$ & $27(61,4 \%)$ \\
\hline Tidak bekerja & $14(82,3 \%)$ & $3(17,6 \%)$ & $17(38,6 \%)$ \\
\hline \multicolumn{4}{|l|}{ Pendapatan (Rp) } \\
\hline$<1.000 .000$ & $14(82,4 \%)$ & $3(17,6 \%)$ & $17(38,6 \%)$ \\
\hline $1.000 .000-2.000 .000$ & $14(63,6 \%)$ & $8(36,4 \%)$ & $22(50 \%)$ \\
\hline$>2.000 .000$ & $3(60 \%)$ & $2(40 \%)$ & $5(11,4 \%)$ \\
\hline \multicolumn{4}{|l|}{ Aktivitas Fisik (n,\%) } \\
\hline Berat & $11(65 \%)$ & $6(35 \%)$ & $17(38,6 \%)$ \\
\hline Sedang & $9(64 \%)$ & $5(36 \%)$ & $14(31,8 \%)$ \\
\hline Ringan & $11(85 \%)$ & $2(15 \%)$ & $13(29,5 \%)$ \\
\hline \multicolumn{4}{|l|}{ Tingkat Stress (n,\%) } \\
\hline Normal & $23(72 \%)$ & $9(28 \%)$ & $32(72,7 \%)$ \\
\hline Sedang & $11(85 \%)$ & $2(15 \%)$ & $13(25 \%)$ \\
\hline Berat & - & $1(100 \%)$ & $1(2,3 \%)$ \\
\hline
\end{tabular}


Tabel 2 . Gambaran Rerata Status Gizi, Kualitas Tidur dan Kualitas Hidup

\begin{tabular}{|c|c|c|c|c|c|c|}
\hline Variabel & $\begin{array}{c}\text { Kualitas } \\
\text { Hidup Baik }\end{array}$ & $\begin{array}{c}\text { Kualitas } \\
\text { Hidup Buruk }\end{array}$ & $n(\%)$ & Min & Maks & Rerata \\
\hline Status Gizi $\left(\mathrm{kg} / \mathrm{m}^{2}\right)$ & & & & 15,8 & 37 & 27,28 \\
\hline Kurang & $1(50 \%)$ & $1(50 \%)$ & $2(4,5 \%)$ & & & \\
\hline Normal & $9(75 \%)$ & $3(25 \%)$ & $12(27,3 \%)$ & & & \\
\hline Overweight & $5(83 \%)$ & $1(17 \%)$ & $6(13,6 \%)$ & & & \\
\hline Obesitas & $8(33 \%)$ & $16(67 \%)$ & $24(54,5 \%)$ & & & \\
\hline Kualitas tidur (n,\%) & & & & 1 & 13 & 7,23 \\
\hline Baik & $13(45 \%)$ & $16(55 \%)$ & $29(65,9 \%)$ & & & \\
\hline Tidak Baik & $5(33 \%)$ & $10(77 \%)$ & $15(34,1 \%)$ & & & \\
\hline Kualitas hidup (n,\%) & & & & 22 & 91 & 63,27 \\
\hline Baik & & & $31(70,5 \%)$ & & & \\
\hline Tidak Baik & & & $13(29,5 \%)$ & & & \\
\hline
\end{tabular}

Tabel 3. Hubungan Status Gizi, Kualitas Tidur, Tingkat Stress dan Kualitas Hidup

\begin{tabular}{lcc}
\hline \multicolumn{1}{c}{ Variabel } & $\mathbf{r}$ & $\boldsymbol{p}$ \\
\hline Status Gizi & 0,251 & 0,101 \\
Kualitas Tidur & $-0,545$ & 0,000 \\
Tingkat stress & $-0,442$ & 0,003 \\
\hline
\end{tabular}

Tabel 1 menunjukan karateristik subjek penelitian. Usia subjek pada penelitian ini berkisar antara $60-74$ tahun. Subjek terdiri dari 20 orang perempuan dan 24 orang laki-laki dengan rata - rata usia 65,09 tahun. Sebagian besar subjek $(79,5 \%)$ masih memiliki pasangan dan sebesar $75 \%$ subjek tinggal dengan pasangannya. Sebagian besar subjek $(93,2 \%)$ memiliki pendidikan akhir di tingkat SD. Sebesar $61,4 \%$ subjek masih bekerja dan sebesar 50\% subjek memiliki pendapatan sebesar 1.000 .000 hingga 2.000.000 tiap bulannya. Sebesar 38,6\% subjek masih melakukan aktivitas fisik berat dan sebesar $72,7 \%$ subjek memiliki tingkat stress normal.

Tabel 2 menunjukan gambaran rerata IMT, kualitas tidur dan kualitas tidur subjek. Rerata IMT subjek sebesar 27,28. Rerata kualitas tidur subjek sebesar 5,82 dan rerata kualitas hidup subjek 63,27. Sebesar $54,5 \%$ subjek mempunyai status gizi obesitas, $34,1 \%$ subjek memiliki kualitas tidur yang tidak baik dan $70,5 \%$ memiliki kualitas hidup yang baik.

Tabel 3 menunjukan hasil uji korelasi menggunakan uji Rank Spearman. Hasil uji korelasi didapatkan bahwa data status gizi tidak ada hubungan dengan kualitas hidup karena $(\mathrm{p}=0,101)$. Berdasarkan tabel korelasi menunjukan bahwa data kualitas tidur dan tingkat stress memiliki hubungan dengan kualitas hidup karena nilai $(\mathrm{p}=0,000, \mathrm{r}=-0,545)$ dan $(\mathrm{p}=0,003, \mathrm{r}=-0,442)$. Semakin tinggi skor kualitas tidur dan tingkat stress maka semakin rendah kualitas hidupnya.

\section{PEMBAHASAN}

Status gizi adalah gambaran dari keadaan keseimbangan gizi dalam bentuk variabel tertentu.
Penurunan asupan makan pada lanjut usia disebabkan oleh masalah fisiologis seperti terjadi gangguan pencernaan dan malabsorbsi zat gizi yang dapat menyebabkan terjadinya malnutrisi. Malnutrisi merupakan keadaan defisiensi, kelebihan atau ketidakseimbangan protein, energi,dan zat gizi lain yang dapat mengganggu fungsi tubuh. Malnutrsi pada lanjut usia dapat berupa obesitas, malnutrisi energi protein dan defisiensi vitamin a dan mineral. Sebanyak $54,5 \%$ subjek mempunyai status gizi obesitas. Obesitas berkaitan dengan penyakt diabetes, penyakit jantung, tekanan darah dan darah tinggi ${ }^{10}$.

Status kesehatan lanjut usia dipengaruhi oleh ada tidaknya penyakit dalam tubuh lanjut usia. Lanjut usia yang tidak memiliki keluhan penyakit akan mampu melakukan aktivitas dan kegiatannya sendiri. Riwayat penyakit subjek antara lain hipertensi dan asam urat dalam satu bulan terakhir ${ }^{11}$. Penyakit tersebut masuk dalam kategori penyakit tidak menular yang sering terjadi pada lanjut usia karena fugsi fisiologis yang mengalami penurunan akibat proses degeneratif. Masalah kesehatan ini dapat menyebabkan menurunnya kualitas hidup lanjut usia.

Dari hasil uji Rank Spearman dapat diketahui bahwa tidak terdapat hubungan antara status gizi dan kualitas hidup $(\mathrm{p}=0,101, \mathrm{r}=0,251)$. Hal ini berbanding terbalik dengan penelitian yang dilakukan oleh Fitri (2012) mengenai hubungan status gizi dengan kualitas hidup geriatri di posyandu lansia di Surakarta yang menunjukan terdapat hubungan yang signifikan antara status gizi dengan kualitas hidup $(\mathrm{p}=0,002)$. Perbedaan hasil kemungkinan disebabkan oleh perbedaan perhitungan tinggi lutut yang akan dikonversikan menjadi tinggi badan. Penelitian yang dilakukan oleh Fitri menggunakan persamaan yang ditemukan oleh Fatmah (2010) yaitu TB pria $=59,1$ $+(2,08 \times \mathrm{TL})$ dan TB wanita $=75+(1,91 \times \mathrm{TL})$ sedangkan penelitian ini menggunakan persamaan yang ditemukan oleh kemenkes (2017) yaitu TB pria $=56,343+(2,102 \times \mathrm{TL})$ dan TB wanita $=62,682+$ $(1,889 \times \mathrm{x}$ TL $) .{ }^{12}$ Penelitian ini juga berbanding terbalik dengan penelitian yang dilakukan oleh Nursilmi 
(2017) mengenai hubungan status gizi dan kesehatan di dua lokasi berbeda. Perbedaan hasil kemungkinan disebabkan oleh perbedaan instrumen yang digunakan. Penelitian yang dilakukan oleh Nursilmi (2017) menggunakan BB, TB, dan LILA untuk menentukan status gizinya sedangkan pada penelitian ini menggunakan $\mathrm{BB}$ dan TL yang dikonversi menjadi TB. Perbedaan populasi juga dapat menjadi faktor penyebab perbedaan hasil. Penelitian yang dilakukan oleh Nursilmi (2017) menggunakan subjek dengan rentang umur 60 sampai 90 tahun, sedangkan penelitian ini menggunakan subjek dengan rentang umur 60 sampai 74 tahun. ${ }^{13}$

Distribusi kualitas tidur responden menunjukkan sebagian besar adalah baik. Kebutuhan tidur akan berkurang dengan berlanjutnya usia. Pada usia 12 tahun kebutuhan untuk tidur adalah 9 jam, berkurang menjadi 8 jam pada usia 20 tahun, tujuh jam pada usia 40 tahun, enam setengah jam pada usia 60 tahun, dan enam jam pada usia 80 tahun. Kualitas tidur pada kelompok usia lanjut cenderung mengalami penurunan, pada usia 65 tahun mereka yang tinggal di rumah setengahnya diperkirakan mengalami penurunan kualitas tidur dan dua pertiga dari mereka yang tinggal di tempat perawatan usia lanjut juga mengalami penurunan kualitas tidur. ${ }^{14}$ Mereka cenderung susah tidur karena mereka terlalu banyak memikirkan hal - hal yang meresahkan fikiran. Pada usia lanjut tersebut tentunya ingin merasakan tidur enak dan nyaman setiap hari, yang merupakan indikator kebahagiaan dan derajat kualitas hidup. Sedangkan penurunan kualitas tidur dianggap sebagai bentuk paling ringan dari gangguan mental.

Hasil uji Rank Spearman disimpulkan ada hubungan kualitas tidur dengan kualitas hidup pada lanjut usia di kelurahan kalisegoro, dimana semakin tinggi kualitas hidup maka semakin baik kualitas tidurnya. Hasil penelitian ini didukung oleh penelitian yang dilakukan oleh Pereira yang meneliti hubungan pola tidur dengan kualitas hidup lanjut usia. Peneliti ini menyimpulkan bahwa ada hubungan antara pola tidur dengan kualitas hidup lanjut usia. Tidur merupakan salah satu fenomena dasar yang penting bagi kehidupan manusia, kurang lebih dari kehidupan manusia dijalankan dengan tidur. Proses degenerasi pada lansia menyebabkan waktu tidur yang efektif semakin berkurang, dan menyebabkan tidak tercapainya kualitas tidur yang adekuat dan menyebabkan berbagi macam keluhan tidur. Prevalensi pemenuhan gangguan pemenuhan kebutuhan tidur pada lansia cukup meningkat yaitu sekitar 76\%. Kelompok lansia lebih mengeluh mengalami sulit tidur sebanyak $40 \%$, sering terbangun pada malam hari sebanyak $30 \%$ dan sisanya gangguan pemenuhan tidur lain. ${ }^{14}$
Berdasarkan hasil analisis statistik dengan menggunakan uji Rank Spearman didapatkan nilai $\mathrm{p}$ value sebesar 0,003, dapat disimpulkan bahwa ada hubungan yang signifikan antara tingkat stress dengan kualitas hidup lanjut usia. Nilai korelasi sebesar 0,442 dan bernilai negati artinya semakin tinggi tingkat stress maka semakin menurun kualitas hidup lanjut usia, begitu juga sebaliknya.

Hasil penelitian ini sesuai dengan teori yang dikemukakan oleh Octavianty (2013) yang menyatakan bahwa stress merupakan salah satu faktor yang mempengaruh kualitas hidup. ${ }^{15}$ Jika dalam kehidupannya lanjut usia mengalami situasi yang menekan atau terjadi perubahan kondisi kualitas hidupnya akan menjadi buruk, namun bila ia memiliki kemampuan serta kesempatan untuk menghadapi dan mengontrol keadaan yang dialaminya maka orang tersebut dapat mempertahankan kondisi kualitas hidupnya pada arah yang lebih positif. Hasil penelitian ini juga sejalan dengan hasil penelitian Zainuddin (2015) yang menunjukkan ada hubungan antara stres dengan kualitas hidup penderita diabetes mellitus tipe 2 di RSUD Arifin Achmad Pekanbaru. ${ }^{16}$

Selain status gizi, kualitas tidur dan tingkat stress kemungkinan terdapat faktor lain yang dapat mempengaruhi faktor kualitas hidup lanjut usia seperti status pernikahan, tinggal dengan siapa, pendidikan akhir, pekerjaan, pendapatan dan aktivitas fisik.

\section{SIMPULAN}

Tidak terdapat hubungan status gizi dengan kualitas hidup pada lanjut usia di kelurahan kalisegoro kecamatan gunungpati kota semarang. Terdapat hubungan kualitas tidur dengan kualitas hidup pada lanjut usia di kelurahan kalisegoro kecamatan gunungpati kota semarang. Terdapat hubungan tingkat stress dengan kualitas hidup pada lanjut usia di kelurahan kalisegoro kecamatan gunungpati kota semarang.

Lansia hendaknya mengikuti program program yang direncangkan oleh pemerintah untuk menjaga kualitas hidup lanjut usia, misalnya kegiatan posyandu lanjut usia. Keaktifan lanjut usia dalam program tersebut diharapkan dapat meningkatkan kualitas hidup lanjut usia dengan terkontrolnya kondisi kesehatan lanjut usia. Keluarga hendaknya memberikan dukungan yang baik kepada lanjut usia seiring dengan penurunan kemampuan dan fisik lanjut usia. Dukungan keluarga yang baik diharapkan dapat menjaga kesehatan lanjut usia baik secara fisik maupun psikis sehingga kualitas hidup lanjut usia dapat terjaga. 


\section{DAFTAR PUSTAKA}

1. Darmojo B, Martono H. Buku Ajar Geriatri. Jakarta: Balai Penerbit Fakultas Kedokteran Universitas Indonesia; 2006.

2. Arisman. Gizi dalam Daur kehidupan : Buku Ajar Ilmu Gizi. Ed.2. Jakarta: Penerbit Buku Kedokteran EGC; 2008.

3. Kemenkes RI. Analisis Lansia di Indonesia. Jakarta: Kemenkes RI; 2017.

4. BPS Indonesia. Statistik Penduduk Lanjut Usia 2017. Jakarta: BPS RI; 2018.

5. Reno RB. Hubungan Status Interaksi Sosial dengan Kualitas Hidup Lansia di Panti Wreda Dharma Bhakti Surakarta [internet]. 2010. [cited 2018 July 16]. Available from: http://etd.eprints.ums.ac.id/

6. Burhan NIK, Taslim NA, Bahar B. Hubungan Care Giver Terhadap Status Gizi dan Kualitas Hidup Lansia Pada Etnis Bugis. [internet]. 2013. JST Kesehatan, Juli 2013, Vol. 3 No. 3: 264-273. [cited 2018 july 16] http://pasca.unhas.ac.id/jurnal/files/68ff898140f9 7d2bb6327c064d778ef.pdf

7. Tel Hatice. Sleep quality and quality of life among the elderly people. Neurology, phychiatry and brain research. 2013; 19: 48-52.

8. Silvinasari, IA. Faktor - Faktor yang Berhubungan Dengan Kualitas Tidur yang Buruk Pada Lansia di Desa Wonojati Kecamatan
Jenggawah Kabupaten Jember [skripsi]. 2012. [cited 2018 July 19]

9. Komisi Nasional Lanjut Usia. Profil Penduduk Lanjut Usia Tahun 2009. Jakarta: Komisi Nasional Lanjut Usia; 2010.

10. Umami P. Hubungan kualitas tidur dengan fungsi kognitif tekanan darah pada lansia di desa pasuruan. JFIK UMMagelang, No.1 Vol.1,2013.

11. Muzamil M. Hubungan antara tingkat aktifitas fisik dengan fungsi kognitif pada Usila di kelurahan jati kecamatan padang timu. Jurnal kesehatan andalas. Vol. 3;2 - 2014.

12. Andaru F. Hubungan status gizi dengan kualitas hidup geriatri di posyandu lansia ngudi sehat bibis baru nusukan banjarsari surakarta [skripsi]. 2012. [cited 2019 July 19]

13. Nursilmi. Hubungan status gzi dan kesehatan dengan kualitas hidup lansia di dua lokasi berbeda. JURNAL MKMI, Vol. 13 No. 4, 2017.

14. Chasanah N. Hubungan kualitas tidur dengan kualitas hidup pada lanjut usia di kelurahan karangasem kecamatan laweyan Surakarta. [skripsi]. 2012. [cited 2018 July 19]

15. Octaviyanti, R. Kualitas Hidup (Quality Of Life) Seorang Penderita Tuberkulosis (TB). 2013. Surabaya : UIN Sunan Ampel.

16. Azizah R. Hubungan antara tingkat stress dengan kualitas hidup lanjut usia hipertensi di wilayah kerja puskesmas wonopringgo pekalongan. 2016. The $4^{\text {th }}$ Univesity Research Coloquium. 